\title{
Assessment of the lead and cadmium contamination levels in the Lublin Region wetlands using mallards (Anas platyrhynchos) as a contamination vector
}

\author{
H. Bojar ${ }^{1} \&$ I. Bojar ${ }^{2}$ \\ ${ }^{I}$ National Medical Inspection, Regional Sanitary Station, Lublin, Poland \\ ${ }^{2}$ Chair and Department of Health Protection Management and \\ Economics, Medical University, Lublin, Poland
}

\begin{abstract}
Human activity emits vast amounts of heavy metals into the environment. Toxic elements that permeate through the biosphere are incorporated into the trophic chain where they are harmful to all living organisms. The aims of this research were: identification of risks and dangers to the environment in the Lublin Region associated with contamination of selected organs of the mallards by toxic elements; determination of concentration levels of selected heavy metals $(\mathrm{Pb}$, $\mathrm{Cd}$ ) in the organs and tissues of mallards (Anas platyrhynchos); an attempt to identify the organs that would allow quick and unambiguous establishment of the mallards' condition, determined by the accumulation of toxic elements; assessment of usefulness of the mallard muscle tissue for human consumption in the context of applicable legal regulations being in force in Poland.

The concentration of polluting heavy metals was ascertained using the atomic absorption spectrometry method (AAS). The highest average concentration of cadmium was found in the kidneys of mallards bred in the Przytoczno animal farm. The highest average concentration of lead was found in the livers of mallards bred in the animal farm in Przytoczno in 2001; in 2002 the highest average concentration of lead was identified in the livers of mallards culled in the Częstoborowice area.

The highest concentration of lead $(\mathrm{Pb})$ in the organisms of mallards was found in their livers, while the highest concentration of cadmium (Cd) was observed in the kidneys. There is a strict link between the levels of heavy metal concentration in the organisms of examined birds and the area where the research samples were taken. The quality of fodder used in mallard farming should be monitored in order to reduce the risks of heavy metal contamination. Based on the research findings it is impossible to identify the organs that would allow quick and unambiguous establishment of the mallards' condition, determined by the accumulation of toxic elements. The observed levels of concentrations of lead and cadmium are harmless to consumers. High concentration levels of heavy metals in the examined organs of the mallards found in some cases justify further monitoring of the environment.
\end{abstract}

Keywords: mallards, heavy metals, concentration, environment. 


\section{Introduction}

Industrial centres are major pollutants emitting vast amounts of heavy metals into the environment [5,9]. All elements, including toxic substances are accumulated in the soil, plants animals, and therefore permeate through human organisms. Pollutions produced by the ore mining industry brought about extremely high concentrations of heavy metals in the soil. This is the reason why the environmental burden is extremely severe in rural areas, where researchers observe that both plants and animals have higher concentrations of heavy metals. Ineffective municipal sewage treatment technologies, or the lack of sewage treatment plants in some places, landfills and industrial waste material dumps are also responsible for the increased levels of heavy metal contamination. Moreover, agriculture itself by the intense use of fertilizers and other chemicals is a significant contributor of heavy metals. Heavy metals are present in the solid and liquid manure used in farming.

Toxic elements that permeate through the biosphere are incorporated into the trophic chain. Increased concentration of toxic elements upsets the biological equilibrium of existing ecosystems $[13,14]$.

An array of unconditionally toxic elements includes lead $(\mathrm{Pb})$ and cadmium (Cd). Lead in the soil is relatively poorly absorbed by plants. Most of this element found in plants stems from precipitations. Lead permeates through animals largely in a form of tetraethyl lead released in the process of gasoline combustion [1]. Toxicity of lead manifests itself in the disturbances of blood production, heme synthesis, which results in damage to the nervous system, inhibited haemoglobin synthesis as well as serious disturbances in the kidney and liver functions [2].

Cadmium is one of the most dangerous environmental toxins. It is quite easily absorbed by plants and with the fodder cadmium gets into the animal organisms. Cadmium penetrates human and animal organisms mainly through alimentary tracts. The element is seldom inhaled. Accumulation of cadmium in animals and humans may be a major cause of kidney canals dysfunctions and cancers [12]. In the human organisms, cadmium displaces calcium from the bones, which results in the itai-itai disease. The disease manifests itself in the backbone distortion, pains in loins, pains in the muscles and legs, duck walk, and breakable bones [2].

Previous research carried out in many countries proved strict links between environmental pollutions and accumulation of heavy metals in organisms [8]. Since the birds are located higher in the trophic chain, they much better than non-vertebrates reflect the hazards resulting from contamination to the human organisms [7].

The main objectives of the research included:

1. Determination of concentration levels of selected heavy metals $(\mathrm{Pb}, \mathrm{Cd})$ in the organs and tissues of mallards (Anas platyrhynchos).

2. Identification of risks and dangers to the environment in the Lublin Region associated with contamination of selected organs of the mallards by some toxic elements. 
3. An attempt to identify the organs that would allow quick and unambiguous establishment of the mallards' condition, determined by the accumulation of toxic elements.

4. Assessment of usefulness of the mallard muscle tissue for human consumption in the context of applicable legal regulations being in force in Poland.

\section{Research material and method}

The research material was collected in the area of 4 reservoirs located in Przytoczno, Częstoborowice, Tuligłowy, and Mosty. Over a 2-year period a total of 120 birds were examined. In 2001 the research samples were taken from 10 mallards in Przytoczno, 16 mallards in Częstoborowice and 16 specimens from Mosty. In 2002 samples were taken from 9 mallards in Przytoczno, 24 mallards in Częstoborowice, 24 in Tuligłowy and 21 in Mosty.

The wild birds were culled in the hunting districts in autumn respecting closed seasons (between 15 Aug. and 20 Dec.) using a double-barrelled gun cal. 12 and the lead shot Nos. 4 and 6. The research reference group was composed of 19 mallards culled in the animal farm in Przytoczno.

The concentration of polluting elements in collected samples of organs and tissues was ascertained using the atomic absorption spectrometry method (AAS). The AAS limits of detection (LOD) are: $0.001 \mu \mathrm{g} / \mathrm{g}$ for cadmium, and $0.001 \mu \mathrm{g} / \mathrm{g}$ for lead. All detected concentrations of heavy metals were converted to the wet weight values (w.w.).

Returned findings were subjected to further statistical analysis. The t-Student distribution was employed to assess the relevance of correlation coefficient.

Table 1.

\begin{tabular}{|l|c|c|c|}
\hline \multirow{2}{*}{ Place of sample collection } & \multicolumn{3}{|c|}{ Number of examined specimens } \\
\cline { 2 - 4 } & 2001 & 2002 & Total \\
\hline Przytoczno & 10 & 9 & 19 \\
\hline Częstoborowice & 16 & 24 & 40 \\
\hline Tuligłowy & 0 & 24 & 24 \\
\hline Mosty & 16 & 21 & 37 \\
\hline Total & 42 & 78 & 120 \\
\hline $\begin{array}{l}\text { Average mass }(\mathrm{kg}) \\
\text { Range }\end{array}$ & 0.96 & 1.01 & 0.99 \\
\hline
\end{tabular}

\section{Research findings}

\subsection{Concentration of lead}

In 2001 the highest average concentration of lead $(\mathrm{Pb})$ was found in the livers of mallards bred in the animal farm in Przytoczno $(1.22 \mathrm{mg} / \mathrm{kg})$, while the lowest 
concentration was found in the livers of mallards culled in Częstoborowice $(0.64 \mathrm{mg} / \mathrm{kg})$. Observed difference has statistical relevance.

In 2002 the highest average concentration of lead was identified in the livers of mallards culled in the Częstoborowice area $(0.90 \mathrm{mg} / \mathrm{kg})$. The lowest concentration of lead was found in the livers of specimens culled in Tuligłowy $(0.49 \mathrm{mg} / \mathrm{kg})$. The average concentration of lead in the livers of mallards culled in Mosty was $0.75 \mathrm{mg} / \mathrm{kg}$. The difference between concentration of lead established in Mosty and Tuligłowy has statistical relevance. The average concentration of lead in the livers of mallards bred in the Przytoczno animal farm was equal to $0.51 \mathrm{mg} / \mathrm{kg}$. The differences between the lead concentrations observed in Częstoborowice and Przytoczno have statistical relevance.

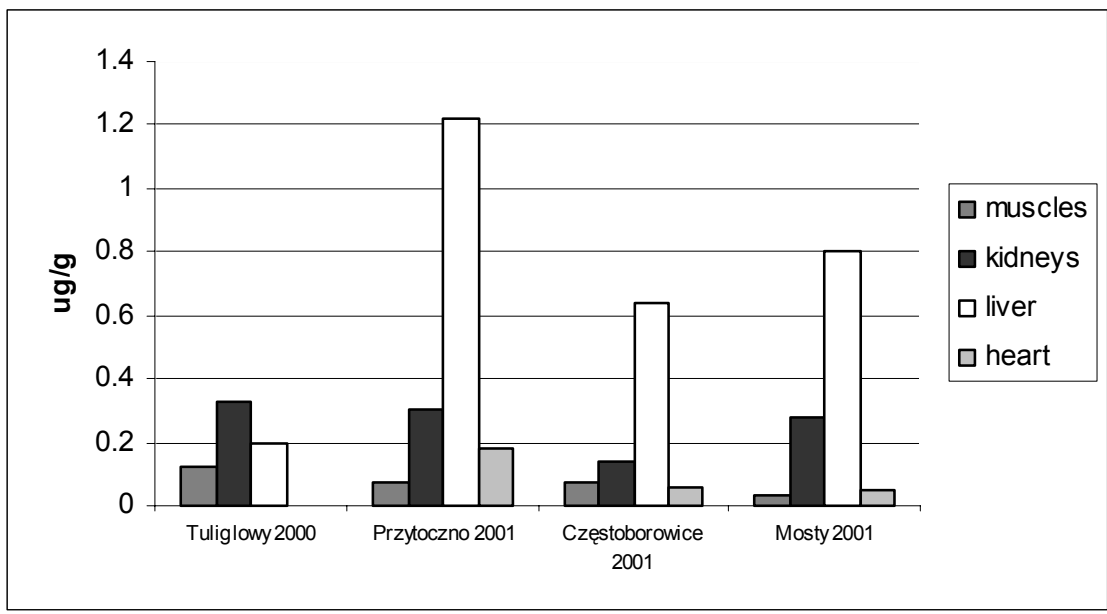

Figure 1: Concentration of lead $(\mathrm{Pb})$ in the organs of mallards in 2000 and 2001 .

\subsection{Concentration of cadmium}

In 2001 the highest average concentration of cadmium $(\mathrm{Cd})$ was found in the kidneys of mallards bred in Przytoczno $(0.87 \mathrm{mg} / \mathrm{kg})$, lower in the specimens culled in Mosty $(0.19 \mathrm{mg} / \mathrm{kg})$, while the lowest concentration of cadmium was established in the mallards culled in Częstoborowice $(0.06 \mathrm{mg} / \mathrm{kg})$. The difference between the concentration of cadmium observed in Mosty and Częstoborowice is of statistical relevance.

The research found that in 2002 the levels of cadmium concentration in the kidneys of mallards culled in the area of reservoirs in Częstoborowice, Mosty and Tuligłowy and those bred in the Przytoczno animal farm varied markedly. The highest average concentration of cadmium $(\mathrm{Cd})$ was found in the kidneys of specimens bred in the Przytoczno animal farm $(0.65 \mathrm{mg} / \mathrm{kg})$, lower in the mallards culled in Tuligłowy $(0.24 \mathrm{mg} / \mathrm{kg})$ and Mosty $(0.18 \mathrm{mg} / \mathrm{kg})$, while the lowest concentration of cadmium was observed in the kidneys of mallards inhabiting the area of Częstoborowice reservoir $(0.01 \mathrm{mg} / \mathrm{kg})$. The difference 
between the concentration of cadmium in the kidneys of mallards bred in the Przytoczno animal farm and the mallards culled in Mosty and Tuligłowy has statistical relevance. Moreover, statistically relevant is the difference between the concentration of cadmium observed in the kidneys of mallards culled in the area of Częstoborowice reservoir and those culled in Mosty.

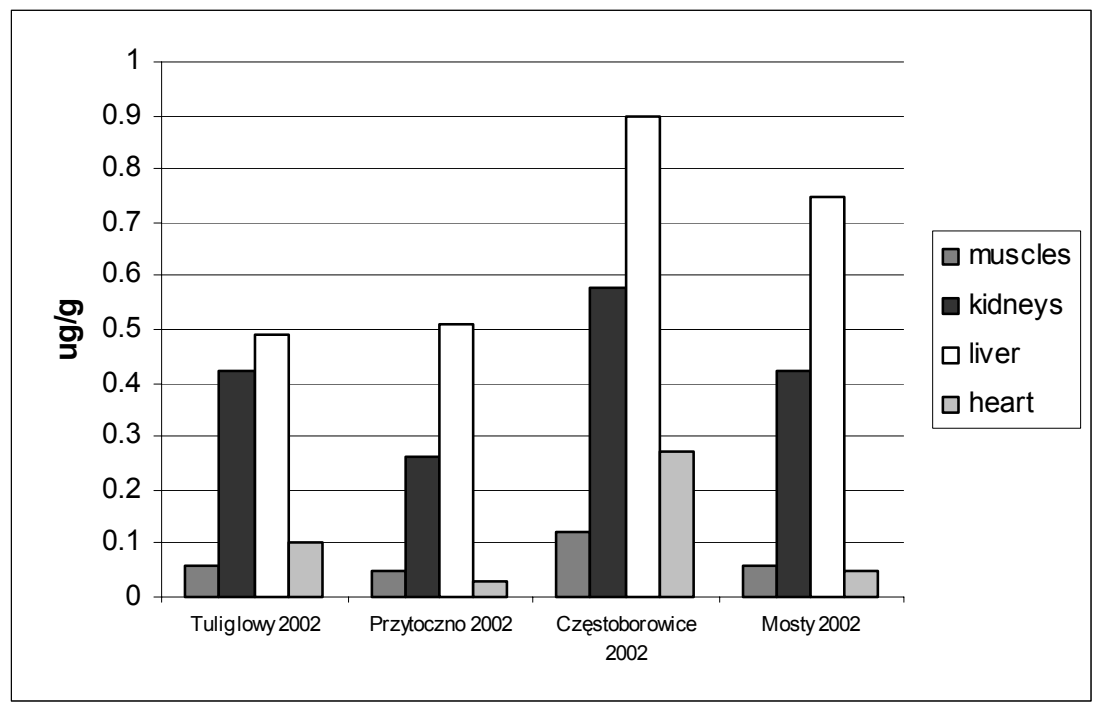

Figure 2: $\quad$ Concentration of lead $(\mathrm{Pb})$ in the organs of mallards in 2002.

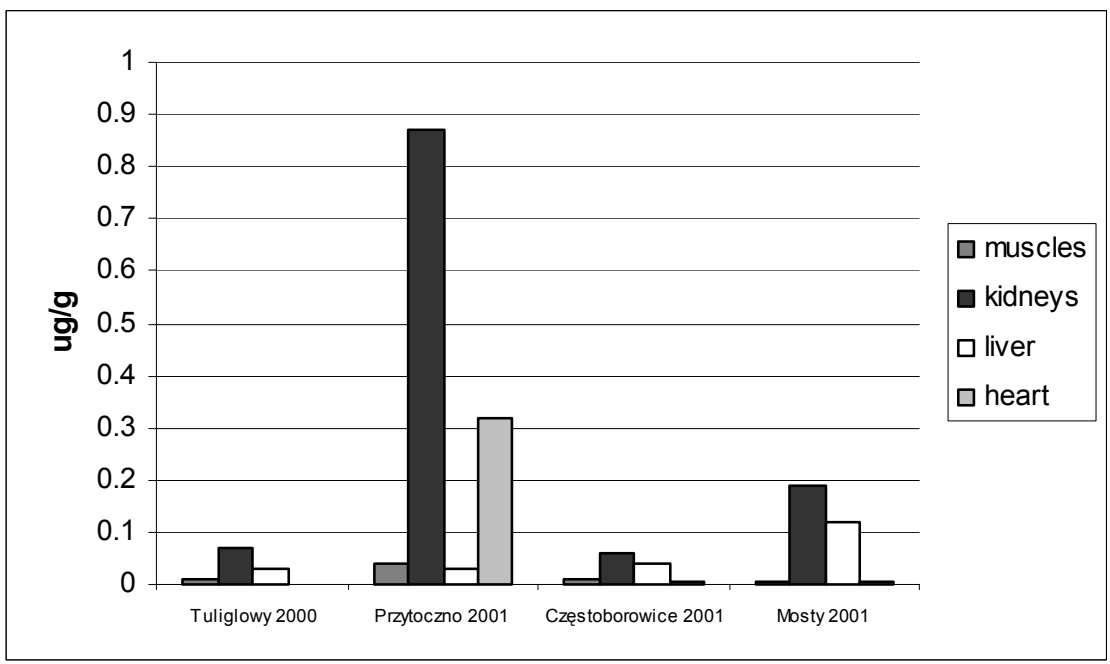

Figure 3: Concentration of cadmium (Cd) in the organs of mallards in 2000 and 2001. 


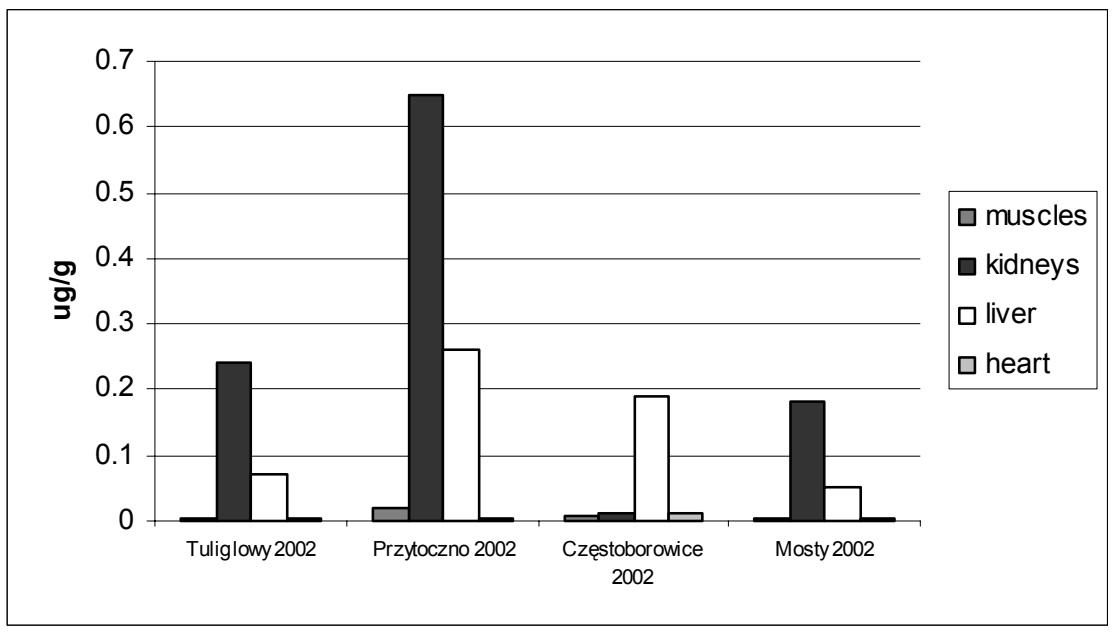

Figure 4: $\quad$ Concentration of cadmium (Cd) in the organs of mallards in 2002.

\section{Discussion}

As a result of the 2-year research carried out in the years 2001-2002 it was found that the highest concentration of lead amounting to $1.22 \mu \mathrm{g} / \mathrm{g}$ was observed in the livers of mallards bred in the Przytoczno animal farm in 2001, while in 2002 the highest concentration was observed in the livers of mallards culled in Częstoborowice $(0.90 \mu \mathrm{g} / \mathrm{g})$. Lower levels of lead concentration were found in the kidneys $(0.14-0.58 \mu \mathrm{g} / \mathrm{g})$. The average concentration of lead in the skeleton muscles was lower than $0.10 \mu \mathrm{g} / \mathrm{g}$. The research findings are similar to those presented by Kalisińska and others [10]. The concentration of lead in the livers ranged from 0.23 to $0.68 \mu \mathrm{g} / \mathrm{g}$ w.w., in the kidneys from 0.20 to $1.48 \mu \mathrm{g} / \mathrm{g} \mathrm{w}$.w., and in the muscles the concentration of lead ranged from 0.51 to $3.67 \mu \mathrm{g} / \mathrm{g} \mathrm{w} . \mathrm{w}$. Previously, Dańczak et al. [3] established that the average concentration of lead and in the kidneys and livers of male mallards equalled $9.16 \mu \mathrm{g} / \mathrm{g}$ and $0.65 \mu \mathrm{g} / \mathrm{g}$ respectively, while in the kidneys and livers of female mallards $-0.25 \mu \mathrm{g} / \mathrm{g}$ and $0.05 \mu \mathrm{g} / \mathrm{g} \mathrm{w} . \mathrm{w}$. respectively. Lower levels of lead concentration in the livers were observed by Felsmann [6]. In some other countries researchers observed markedly higher levels of lead concentration, for instance in Spain, where the average concentration found in the mallard livers was $17(2.0$ to 107.0$) \mu \mathrm{g} / \mathrm{g}$ w.w. [11]. Similar levels of lead concentration were observed by Di Giulio and Scanlon [4].

The research carried out in the years 2001-2002 revealed that the highest levels of cadmium concentration was in the kidneys of mallards bred in the Przytoczno animal farm, i.e. $0.87 \mu \mathrm{g} / \mathrm{g}$ in 2001 and $0.65 \mu \mathrm{g} / \mathrm{g}$ in 2002 . Also the highest level of cadmium concentration was found in the livers of Przytoczno mallards $(0.32 \mu \mathrm{g} / \mathrm{g}$ and $0.26 \mu \mathrm{g} / \mathrm{g}$ respectively). The cadmium concentration in the organs of birds collected in other areas was significantly lower. In their 
research carried out on the mallards collected in the Słońsk sanctuary, Kalisińska et al. [10] established that the average cadmium concentration in the livers was equal to $0.87 \mu \mathrm{g} / \mathrm{g}$, in the kidneys $-7.24 \mu \mathrm{g} / \mathrm{g}$, and in the muscles $0.03 \mu \mathrm{g} / \mathrm{g}$ w.w. Similar high levels of cadmium concentration were observed by Dańczak et al. [3].

The content of heavy metals observed in the organs of mallards reflects concentration of heavy metals found in the water plants such as common duckweed and common reed taken from the natural habitat of mallards. The highest average concentration of cadmium (Cd) was established in 2001 in the samples of common duckweed taken from the ponds in Przytoczno $(0.15 \mu \mathrm{g} / \mathrm{g}$ d.m.) and common reed $-1.79 \mu \mathrm{g} / \mathrm{g}$ d.m. As regards lead $(\mathrm{Pb})$ researchers did not observe any similar regularities [15].

Table 1: The highest permissible concentration of selected pollutants in food.

\begin{tabular}{|l|c|c|}
\hline & $\begin{array}{c}\text { Edible beef offal, pork offal } \\
\text { and giblets }\end{array}$ & $\begin{array}{c}\text { Beef muscles, pork muscles } \\
\text { and poultry muscles }\end{array}$ \\
\hline $\mathrm{Pb}(\mathrm{max} . \mathrm{mg} / \mathrm{kg})$ & 0.5 & 0.1 \\
\hline $\mathrm{Cd}(\mathrm{max} . \mathrm{mg} / \mathrm{kg})$ & 0.5 & 0.05 \\
\hline
\end{tabular}

Table 2: $\quad$ The number of mallards where excessive levels of heavy metal concentration were found.

\begin{tabular}{|l|l|c|c|}
\hline \hline \multicolumn{2}{|c|}{} & Edible giblets & Poultry muscles \\
\hline \multirow{2}{*}{$\mathrm{Pb}$} & 2001 & 24 & 3 \\
\cline { 2 - 4 } & 2002 & 71 & 14 \\
\hline \multirow{2}{*}{$\mathrm{Cd}$} & 2001 & 4 & 2 \\
\cline { 2 - 4 } & 2002 & 1 & 1 \\
\hline \hline
\end{tabular}

The concentration of heavy metals in tissues and organs of mallards as game birds should be considered in the context of its impact on the consumers and their health.

The following table displays the highest permissible concentration of selected pollutants in food set out by EC Regulation No 466/2001 of 8 March 2001 setting maximum levels for certain contaminants in foodstuffs.

The research that was carried out over a 2-year period in 2001-2002 and involved a total of 120 birds, found 24 cases of excessive concentration of lead in the livers in 2001 and 49 in 2002. As regards the kidneys, excessive concentration of lead was found only in 2002 ( 22 cases), while in the skeleton muscles excessive concentrations of this element was observed in 3 cases in 2001 and 14 in 2002. 
As regards the concentration of cadmium in the organs and tissues of mallards collected in 2001, excessive concentrations of this element were found in the kidneys of 4 specimens, in the muscles of 2 mallards, while in the livers the concentration of cadmium was within permissible limits. In 2002, there was only 1 occurrence of excessive concentration of cadmium in the livers, kidneys, and muscles.

The following table presents the number of mallards where excessive levels of heavy metals concentration were found.

Considering that only the mallard carcass is consumed, although sporadically, observed concentration levels do not pose any hazard to human health.

\section{Conclusion}

1. The highest concentration of lead $(\mathrm{Pb})$ in the organisms of wild ducks was found in their livers, while the highest concentration of cadmium (Cd) was observed in the kidneys.

2. There is a strict link between the levels of heavy metals concentration in the organisms of examined birds and the area where the research samples were took.

3. The quality of fodder used in the wild ducks farming should be monitored in order to reduce the risks of heavy metals contamination.

4. Based on the research findings it is impossible to identify the organs that would allow quick and unambiguous establishment of the mallards' condition, determined by the accumulation of toxic elements.

5. The observed levels of concentration of lead and cadmium are harmless to the consumers.

6. High concentration levels of heavy metals in examined organs of the wild ducks found in some cases justify further monitoring of the environment.

\section{References}

[1] Bodak E., Kołacz R., Dobrzański Z.: Metale ciężkie - warunki narażenia i mechanizmy obronne u zwierząt. Medycyna Wet. 10, 619-625, 1996

[2] Chmielnicka J.: Metale i Metaloidy; Toksykologia pod redakcją Witolda Seńczuka Wydawnictwo Lekarskie PZWL Warszawa 1999

[3] Dańczak A., Ligocki M. i Kalisińska E.: Heavy metals in the organs of anseriform birds. Polish Journal of Environmental Studies 6, pp. 39-42, 1997

[4] Di Giulio R.T., Scanlon P.F.: Heavy metals in tissues of waterfowl from the Chesapeake Bay, USA. Environ. Pollut. Series A 35, pp. 29-48, 1984

[5] Falandysz J., Kotecka W., Kannan K.: Mercury, lead, cadmium, manganese, copper, iron and zinc concentration in poultry, rabbit and sheep from the northern part of Poland. Sci. Total Environ. 141, 51-57, 1994

[6] Felsmann M.Z.: Poziom wybranych ksenobityków i zmiany morfologiczne narządów wewnętrznych u kaczek krzyżówek (Anas pltyrhynchos L.) i 
łysek (Fulica atra L.). Rozprawa doktorska Akademia Rolnicza im. Michała Oczapowskiego Wydz. Med. Wet. Zakład Weterynarii Sądowej i Administracji Olsztyn 1998

[7] Furness R.W., Greenwood J.J.D.: Birds as monitors of environmental change. Chapman and Hall 1993

[8] Gochfeld M.: Spatial Patterns in a Bioindicator: Heavy Metal and Selenium Concentration in Eggs of Herring Gulls (Larus argentatus) in the New York Bight. Arch. Environ. Cont. Toxicol. 33, 63-70, 1997

[9] Hahn E., Ostapczuk P., Ellenberg H., Stoeppler M.: Environmental monitoring of heavy metals with birds as pollution integrating biomonitors: cadmium, lead and copper in magpie (Pica pica) feathers from a heavily polluted and control area. International Conference Heavy Metals in the Environment, 721-723, Athens, 1985

[10] Kalisińska E., Salicki W., Mysłek P., Kavetska K.M., Jackowski A.: Using to biomonitor heavy metal contamination of wetlands in north - western Poland. Sci. Total Environ. 320, pp. 145-161, 2004

[11] Mateo R., Guitart R.: Heavy metals in livers of waterbirds from Spain. Arch. Environ. Cont. Toxicol. 44, pp. 398-404, 2003

[12] Om A.S., Chung K.W., Chung: Effect of cadmium accumulation on renal tissues in broilers. Bull. Environ. Cont. Toxicol. 68, 297-301, 200

[13] Pain D., Pienkowski M.: Farming and Birds in Europe. New York Academic Press. 1997

[14] Walker C.H., Hopkin S.P., Sibly R.M., Peakall D.B.: Podstawy Ekotoksykologii PWN Warszawa 2002

[15] Wałkuska G. Szczepanik M. Bojar H.: Zawartość metali ciężkich w roślinach wodnych pozyskiwanych z różnych akwenów Lubelszczyzny. Annales UMCS Sec DD, Medicina Veterinaria 2003 Vol. 58, s. 189-197 